\title{
Physical education and sports students' attitudes towards inclusive education (The sample of Kocaeli University) ${ }^{1}$
}

\author{
Menşure Aydın ${ }^{2}$ \\ Nejat İra ${ }^{3}$ \\ Bergün Meriç Bingül $1^{3}$ \\ Çiğdem Bulgan ${ }^{4}$
}

\begin{abstract}
The aim of this study was to observe if Physical Education and Sports students' attitudes towards Inclusive Education differ or not. The research was done according to the scanning/screening model. "Personal information form" (2004) - (reformed by Orel and his friends) and "Attitude Scale related to Inclusion" (1995)-(reformed by Antonak \& Larivee and adapted into Turkish by Kircaali \& Iftar ) were used for Kocaeli University School of Physical Education and Sports /Physical Education and Sports Department's 1st grade and the 2nd grade students (121 students) who didn't take the Inclusive Education class and the 3rd and 4th grade students (193 students) who took the Inclusive Education class. In the statistical analysis of the research, frequency values of the data (which were obtained from personal information forms) were surveyed and while analysing the data (obtained from the attitude scale related to inclusion) arithmetic average, standard deviation and t test (for the difference between two groups ) were applied.In statistical analysis and in all parameters numerical difference was seen on the side of the students who took inclusive education class but no statistically significant difference was found . $(P<0,05)$. As a result, it can be said that Inclusive Education class had a positive change on the attitudes of Physical Education teacher candidates towards inclusion.
\end{abstract}

Keywords: Inclusion; Inclusion Applications; Inclusive Education.

\section{Introduction}

Inclusive education is a contemporary education system that is adopted and accepted in our country as well as other countries. The main purpose of the inclusive education is to supply the students needing special education with general education facilities in general education classrooms and to supply the disabled students with an education together with students with no disabilities(Babaoglan -Yilmaz, 2010; Konarand Yildiran, 2012). Education via inclusion is a training application in which the individuals needing special education are given their education in the same environment with their peers who do not have any disabilities. This process includes pre-school, elementary school and secondary school periods (Engin et al., 2014)

In the Enactment of the Law for the Special Education law number 573 in Turkey, the inclusive education is defined as the follows; 'The education of the individuals who need special education is

\footnotetext{
1 This paper was presented at 1st International Conference on Life Long Education and Leadership for All on October 29th-31st, 2015 in Czech Republic.

${ }^{1}$ Assoc. Prof. Dr., Kocaeli University, School of Physical Education and Sports, mensure@kocaeli.edu.tr

${ }^{2}$ Assoc. Prof. Dr., Kocaeli University, Faculty of Education, nejat.ira@gmail.com

${ }^{3}$ Assoc. Prof. Dr., Kocaeli University, School of Physical Education and Sports, bergunmeric@yahoo.com

${ }^{4}$ Haliç University, School of PhysicalEducationand Sports, cigdembulgan@gmail.com
} 
Aydın, M., İra, N., Meriç Bingül, B., \& Bulgan, C.. (2016). Physical education and sports students' attitudes towards inclusive education (The sample of Kocaeli University). Journal of Human Sciences, 13(2), 2839-2846. doi:10.14687/jhs.v13i2.3667

performed by using appropriate techniques and methods at all level education institutions together with their peers led by a well-prepared syllabus.' (Vural, 2010).

Teachers hold a remarkable responsibility for the education of children. The general education classrooms should have the facilities to meet the needs of all students; they should be appropriately designed to make the learning easy; and all students should have the opportunities to participate both in educational and social activities. The students that are included in inclusive education process should be informed beforehand about their peers needing special education so that they will be aware of the situation. So as to apply the process of Inclusive Education successfully, it is necessary to supply the students in need of special education, teachers, and the classrooms with supportive special education services.

The application of the Inclusive education at PE (Physical Education) classes is extremely important. Because PE classes have the potential to let the students take part in a lot of interesting and exciting activities such as running, jumping, leaping andbouncing both individually and as a group game. PE classes are important for thedevelopment of the disabled individuals. PE classes fulfil an extremely important duty for the targeted inclusive education in special education area to put the handicapped students into the same classrooms with the normally developing children (Ozer, 2001) Not only do the inclusive PE classes contribute to the disabled children to comprehend how to perform the sportive activities, but they also contribute the normally developing children to be conscious of being disabled.Inclusive PE classes are also important to encourage the disabled students to take up a sport.

Because these classes prevent them from having illnesses due to being inactive well as helping them to develop physically, play logically and socially. In addition; PE classes help the disabled to control their emotions like aggressiveness, anger and jealousy, which come at as a result of social attitudes or their psychologicalconditions they are in (Sonuç,2012). Therefore, their participation in sport should be an activity which they can do all their lives, It shouldn't be limited only with PE classes at schools (Brittain,2004).

However, teachers should plan their classes appropriate both forthe normal developing children and forthe disabled children and appropriate for what kind of disability they have (Morley et al, 2005).

Our attitudes do not come from birth unlike most of our behaviours. They are learned via training. Parents, friends, mass medium and life styles are some of the important factors that play an important role in acquiring the attitudes. It is especially difficult to ignore the stereotyped, negative, exclusivist, and rejectionist judgements towards the disabled individuals (Sezer, 2012).

Pre-service teachers who had training on inclusive education were observed to have better classroom managements and to have comprehended how to help the handicapped with improving their academic skills. They were also reported that their concern level about the inclusive education lowered; and taking part in different

\section{Method}

General scanning method was applied in this research. Scanning method is an approach aiming to define the phenomenon today or in the past as it is. This research presents PE pre-service teachers' attitudes unchanged as they are. That's why; this research is a descriptive one (Karasar, 1984). 
Aydın, M., İra, N., Meriç Bingül, B., \& Bulgan, C.. (2016). Physical education and sports students' attitudes towards inclusive education (The sample of Kocaeli University). Journal of Human Sciences, 13(2), 2839-2846. doi:10.14687/ihs.v13i2.3667

Participants:The universe of the research consists of students studying at PE and Sport at Kocaeli University, School of Physical Education and Sports. The universe of the research group consists of totally 314 students having education in PE teaching at KOU, School of Physical Education and Sports in 2014/2015 Academic Year. 121 of these students did not receive any inclusive education training $\left(1^{\text {st }} / 2^{\text {nd }}\right.$ grades $)$; and 193 of them were given the inclusive education training $\left(3^{\text {rd }} / 4^{\text {th }}\right.$ grades). 51,3 per cent of the participants in this research are females and 48,7 per cent are males.

Personal Information Form developed by Orel et al in 2004 and 'The Attitude Scale Towards Inclusion' developed by Antonak and Larivee in 1995, adapted to Turkish by Kircaali and Iftar in 1996 was applied as the data collecting tools. Kircaali and Iftar stated in their reports in 1997 that they examined its structural validity with factor analysis and the internal consistency with item analysis. They emphasised that 20 items out of 25 were collected in 5 at the end of the Varimax Rotation in structural validity; Factor Analysis and Scree test.

Cronbach Alpha coefficient of consistence was reported as 0.80 as the indicator of reliability. While analysing the data, all the attitude scores towards inclusion calculated from the PE class pre-service teachers in the sample group wereexamined. While the attitude scale towards inclusion was graded, positive and negative statements were taken into consideration together. The answers category was graded from the positive to the negative as 5,4,3,2,1; and the negative ones were graded like 1,2,3,4,5. The scale was Linkert type scale; and it is replied as the follows; $1=$ " I strongly agree.", 2=" I agree"' ' 3=" I am not sure." 4=" I do not agree." And 5=" I do not agree at all." The scale includes 10 negative statements and they are replied backwards. That's why, the lowest score that can be collected from the scale is 20 and the highest is 100 .

In the statistical analysis of the data collected in this research, frequency values of the data from the Personal Information Form were taken into consideration whereas arithmetic average and standard deviation were used in the evaluation of the data from the Attitude Scale towards Inclusion and itwas applied to determine the difference between these two groups. Mann-Whitney Test was conducted to find 'The Benefits of Inclusion' arithmetic average, standard deviation and the difference between these two groups.

\section{Results}

$\underline{\text { Table 1: Factor }(1,2,4,5) \text { Arithmetic Average and Standard Deviation }}$

\begin{tabular}{|c|c|c|c|c|c|c|}
\hline & $\begin{array}{l}\text { Department/ } \\
\text { Group }\end{array}$ & $\mathrm{N}$ & $\mathrm{AA}$ & $\mathrm{SD}$ & $\mathrm{t}$ & $\mathrm{p}$ \\
\hline Class & Getting & 121 & 20,90 & 4,20 & 1,049 & \\
\hline Management & inclusion & & & & & \\
\hline in inclusion & $\begin{array}{l}\text { Not getting } \\
\text { inclusion }\end{array}$ & 193 & 20,40 & 3,93 & 1,033 & 0,29 \\
\hline $\begin{array}{l}\text { Opinions } \\
\text { about }\end{array}$ & $\begin{array}{l}\text { Getting } \\
\text { inclusion }\end{array}$ & 121 & 10,30 & 2,62 & 1,082 & \\
\hline Inclusion & $\begin{array}{l}\text { Not getting } \\
\text { inclusion } \\
\text { Getting } \\
\text { inclusion }\end{array}$ & 193 & 9,97 & 2,58 & 1,079 & 0,775 \\
\hline of the & & 121 & 5,40 & 1,41 & $-0,663$ & \\
\hline
\end{tabular}


Aydın, M., İra, N., Meriç Bingül, B., \& Bulgan, C.. (2016). Physical education and sports students' attitudes towards inclusive education (The sample of Kocaeli University). Journal of Human Sciences, 13(2), 2839-2846. doi:10.14687/jhs.v13i2.3667

\begin{tabular}{|c|c|c|c|c|c|c|}
\hline disabled & $\begin{array}{l}\text { Not getting } \\
\text { inclusion }\end{array}$ & 193 & 5,60 & 1,61 & $-0,684$ & 0,088 \\
\hline $\begin{array}{l}\text { The negative } \\
\text { effect of the }\end{array}$ & $\begin{array}{l}\text { Getting } \\
\text { inclusion }\end{array}$ & 121 & 5,74 & 1,52 & 70 & \\
\hline Inclusion & $\begin{array}{l}\text { Not getting } \\
\text { inclusion }\end{array}$ & 193 & 5,75 & 1,30 & $\begin{array}{l}-0,0 / 8 \\
-0,076\end{array}$ & 0,095 \\
\hline
\end{tabular}

$* \mathrm{P}<0,05$

According to $t$ test result, where four factors were evaluated, no significant difference was found in any parameters $(\mathrm{P}>0,05)$.

Table 2. Factor (3) Arithmetic Average and Standard Deviation andMann-Whitney U Test tests $\underline{\text { results }}$

\begin{tabular}{|c|c|c|c|c|c|c|}
\hline Factor & $\begin{array}{l}\text { Department/Grou } \\
\mathrm{p}\end{array}$ & $\mathbf{N}$ & $\begin{array}{l}\text { Mean } \\
\text { Rank }\end{array}$ & Sum of Ranks & $\mathrm{Z}$ & $\mathbf{P}$ \\
\hline \multirow[t]{2}{*}{ Benefits of Inclusion } & Getting inclusion & 121 & $\begin{array}{l}164,1 \\
7\end{array}$ & 19864,00 & $-1,036$ & 300 \\
\hline & $\begin{array}{l}\text { Not getting } \\
\text { inclusion } \\
\text { Total }\end{array}$ & $\begin{array}{l}193 \\
314\end{array}$ & $\begin{array}{l}153,3 \\
2\end{array}$ & 29591,00 & & \\
\hline
\end{tabular}

$* \mathrm{P}<0,05$

According to $t$ test result, where four factors were evaluated, no significant difference was found in any parameters $(\mathrm{P}>0,05)$.

Table 3. Factor (3) Arithmetic Average and Standard Deviation andMann-Whitney U Test tests $\underline{\text { results }}$

\begin{tabular}{|c|c|c|c|c|c|c|}
\hline Factor & $\begin{array}{l}\text { Department/Grou } \\
\text { p }\end{array}$ & $\mathbf{N}$ & $\begin{array}{l}\text { Mean } \\
\text { Rank }\end{array}$ & Sum of Ranks & $\mathrm{Z}$ & $\mathbf{P}$ \\
\hline \multirow[t]{2}{*}{ Benefits of Inclusion } & Getting inclusion & 121 & $\begin{array}{l}164,1 \\
7\end{array}$ & 19864,00 & $-1,036$ & ,300 \\
\hline & $\begin{array}{l}\text { Not getting } \\
\text { inclusion } \\
\text { Total }\end{array}$ & $\begin{array}{l}193 \\
314\end{array}$ & $\begin{array}{l}153,3 \\
2\end{array}$ & 29591,00 & & \\
\hline
\end{tabular}

According toMann-Whitney U Test results, where the third factor was evaluated, no significant difference was found between two groups $(\mathrm{P}>0,05)$.

\section{Discussions and Conclusions}

In this research, the effects of the inclusive education training given to the PE pre-service teachers on their attitudes towards inclusion were examined. Even though there was no significant difference between both groups, it was observed that getting this training had a positive effect on their attitudes.

Teachers' opinions about the inclusive education are affected positively by several factors like their education level, the training they had about inclusion and the efficiency of the supportive services. One of the reasons why teachers develop negative attitudes towards inclusive education was determined in many researches that they have a lower level of awareness about the inclusive 
Aydın, M., İra, N., Meriç Bingül, B., \& Bulgan, C.. (2016). Physical education and sports students' attitudes towards inclusive education (The sample of Kocaeli University). Journal of Human Sciences, 13(2), 2839-2846. doi:10.14687/ihs.v13i2.3667

education. In those researches, it was stated that giving pre-service class teachers training on inclusive education had a positive effect on their attitudes towards inclusion (Gokdere,2012).

Even though there are numerous studies that prove the positive effects of inclusion training to change the teachers' attitudes towards inclusive education, there are also studies which say they stay behind the expected (Aral et al.,2012). In his research where Kilic (2012) studied the effects of inclusive education training on pre-school teachers' attitudes towards putting the disabled students into the same classrooms with their normally developing peers; he stated that they had favourable attitudes and there was no significant difference between their opinions. In another similar research, it was also declared that giving pre-service class teachers training on inclusive education did change their opinions about inclusion as there was a significant difference in some statements in the scale (Koçyiğitet al.,2010).

In the research was done by Gozun and Yikmis in 2004, they studied how it affected to inform the pre-service teachers about inclusive education and whether it had any effect on changing their attitudes in a positive way or not. They found out a statistically significant difference in the pre-test and post-test scores of the pre-service teachers in the experimental group from the Attitudes Scale Towards Inclusion. However, no significant difference was found between the pre-test and posttest scores of the pre-service teachers in the control group.

In a research where pre-service teachers' attitudes towards inclusive education were examined, they were observed to have generally favourable attitudes towards the inclusion. Besides these attitudes showed a significant difference according to several demographic variables such as the educational department, whether having information about the individuals needing special education or not, whether having the chance of observing these individuals or not, and whether getting a training about the inclusive education or not (Ozturk et al., 2014).

At the beginning of a research, pre-service teachers were observed to have different concepts for the disabled people and for healthy people. However, at the end of that research they were observed to have changed their opinions about the disabled people and they said they were no different from the healthy people at all. As a result, the study was done for the special education has a great importance and it promotes the level of the students' awareness and changes their concepts in a positive way(Altintas and Sengul,2014).

In many research on inclusive education at different fields it was agreed that most of the teachers lacked information about inclusion (Guven and Cevik,2012). In one of the studies where the attitudes of pre-service teachers to be employed at different positions were examined, it was observed that there was a significant difference between their attitudes according to some variables such as the school they have graduated/are going to graduate. However, no significant difference was found in other variables (Firat, 2014).

In the study called "Inclusive Education in the USA, The Attitudes of Secondary School Teachers towards Inclusive Education" by Mackey (2014); all the teachers had a little special training for working with the disabled students or with students needing some support. They all agreed having a disabled student in their classrooms had a positive effect on their attitudes.

It was stated in many research by many researchers that the attitudes of teachers taking part in inclusive education process and their information level, their being skilled and well-educated on inclusion and disabled children played a remarkable role in the success of this process (Sart et al.,2004; Turkoglu,2007;Gozun and Yikmis,2004;Vural,2010;Ozdemir et al.,2012). 
Aydın, M., İra, N., Meriç Bingül, B., \& Bulgan, C.. (2016). Physical education and sports students' attitudes towards inclusive education (The sample of Kocaeli University). Journal of Human Sciences, 13(2), 2839-2846. doi:10.14687/ihs.v13i2.3667

In the studies performed with 'The Opinions Scale of Inclusion'; it was emphasised that teachers did not have enough and comprehensive training about inclusion; they could not benefit any supportive services; in addition, no supportive services were given to the class teachers who work in inclusive education; the teachers did not have enough equipment so they could not make necessary preparations. Because of these, teachers had negative attitudes towards inclusion programme. As a result of this, it became more difficult to apply this inclusion programme. DikiciSigirtmac et al., (2011) stated that students at undergraduate years should be given trainings about inclusive education both theoretically and practically. They added that expert staff should regularly support teachers giving inclusive education. In the research by Aydin (2014), determined PE teachers' information level about the inclusive education. What she found was as the follows; 32,7 per cent of the PE teachers had training about inclusion, and 67,3per cent of them did not get any training about this. In the comparison of the pre-school teachers' attitudes towards the inclusion in respect to whether they have any disabled children or not in their classrooms; there was found a significant difference in the parameters of the classroom management; opinions about the inclusion, the efficiency of the pre-school teachers and the total value. However, no significant difference was found in the parameters of the benefits of the inclusion; the efficiency of the disabled student; and the negative effects of the inclusion (Secer et al.,2010).

In this research, no significant difference was found between the group who got training on inclusive education and the group who did not $(p=<0,05)$. The reason of this can be explained with the fact that the volunteer students at our school are running physical activities for special groups every year and that our students develop awareness of the disabled while they are running some Social Responsibility Projects.

- 51,3 per cent of the participants of this research are female students and 48.7' per cent of them males.

- $\quad 38.53$ per cent of them had training about inclusion; 61,46 per cent did not.

- 6,7 per cent of the schools (under the Ministry of Education)where the inclusive education was applied, had disabled students. However, 93,3 per cent of these schools did not have any.

- 21 per cent of the students has someone disabled in / around their families; 79,0 per cent of them have no one disabled.

The results of $t$ test and mann-Whithney $U$ test used for statistical analysis illustrate that even though there was a statistically favourable difference for all parameters of those who had training about inclusive education, this difference was not significant $(\mathrm{P}<0,05)$. As a result, it can be said that Inclusive Education class has a positive change on the attitudes of Physical Education teacher candidates towards inclusion

\section{Bibliography}

Altintas E, Sengul S (2014). The evaluation of special education lesson in terms of attitudes towards mainstreaming and attainments, Kafkas University, $e-$ Kafkas Educational Researches Journal, 1(3).

Aral M, Ozcan Ş, Cakmak O O, Birdogan S, Demir N, Gunes A, Deniz E R, TokmakkayaG(2012). http://mebk12.meb.gov.tr/meb iys dosyalar/06/01/334395/dosyalar/2012 12/1811290 4 eitimin,kaynatrmaeitiminderetmentutumlarnaetkisi.pdf (Access Date: 26.08.2015)

Antonak, R. F., \& Larrivee, B. (1995). Psychometric analysis and revision of the opinions relative to mainstreaming scale. Exceptional Children, 62(2), 139-149. 
Aydın, M., İra, N., Meriç Bingül, B., \& Bulgan, C.. (2016). Physical education and sports students' attitudes towards inclusive education (The sample of Kocaeli University). Journal of Human Sciences, 13(2), 2839-2846. doi:10.14687/jhs.v13i2.3667

Aydin M(2014).Assessing knowledge levels of secondary school physical education and sports teachers about inclusive education, Educational Research and Reviews, 9(21), 1116-1124

Babaoglan, E., Yilmaz, S.. (2010). "The efficiency of class teachers in inclusive education" Kastamonu, Education Journal .18(2), 345-354.

Brittain, I. (2004) 'The role of schools in constructing self-perceptions regarding sport and physical education in relation to people with disabilities'. Sport, Education and Society 9 (1), 75-94

Cevik O, Kabasakal, K. (2013).Examining the effects of sportive activities on the socialising the handicapped and their adaptation to the society.International Journal of Social and Economic Sciences 3 (2): 74-83, ISSN: 1307-1149, E-ISSN: 2146-0086,

Demir, M. K., Acar, S. (2011). The opinions of the experienced teachers in inclusive education Kastamonu Education Journal, Vol:19 No:3

Dikici-Sigirtmaç A, Hos G, Abbak A (2011).Solutions and suggestions for the problems faced by the pre-school teachers in inclusion. Ahi Evran University, Kirşehir Educational Faculty Journal (KEFAD) Vol, 12, No 4, page,205-223

Elgin A O, Tösten R, Kaya MD, Köselioğlu YS (2014), The evaluation of manners and point of views related to mainstreamingeducation having responsibilities of students who are in needs of specialeducation for primary education (Example of Kars), Kafkas University Journal of the Institute of Social Sciences, Number 13, Spring 2014, 27-44

Firat $T$ (2014).Examining the attitudes of the pre-service teachers at different fields towards inclusion. Adiyaman University Journal of Social Sciences Institute, Year: 7Issue: 18)

Gokdere M (2012). Examining the attitudes, concerns and reactions of class teachers compared with pre-service class teachers' towards inclusive education. Educational Sciences: Theory \& Practice - 12(4) .Autumn. 2789-2806

GozunO,Yikmiss A (2004). The effects of training on changing the pre-service teachers' attitudes towards inclusion.Ankara University,Educational Sciences Faculty Special Education Journal, 5 (2) 65-77.

Guven E, Cevik B (2012). A Study on the determination of the pre-service music teachers' views about inclusion. (the sample of balikesir university).Journal of Educational and Instructional Studies in the World, Volume: 2 Issue: 1 Article: 22 ISSN: 2146-7463

Ilhan, L (2008), The effect of pe and sports on the level of socialising of the trainable mentally disabled children, Kastamonu Education Journal Vol:16Issue:1, p:315-324

Karasar,N.(1984). Scientific Research Method. Ankara: HacettepeTas Publications.

Kargin, T. 2004 "Inclusion: The definition,development and its principles". Ankara University Educational Sciences Faculty Special Education Journal, 5 (2) 1-13., quoted from:EnginA O, Tosten R, Kaya M D , Koselioglu Y S (2014)The Evaluationof the Elementary School Teachers' Attitudes and Opinions about the Inclusion (the sample ofKars Province )Kafkas University Journal of the Institute of Social Sciences Number 13, 27-44

Kilic A F (2011), The ffect of training pre-school teachers about inclusion of the disabled students; the effect of changing their views, Institute of Social Science / Thesis of Master's Degree

Kircaali Iftar G. (1998). Inclusion and supportive special education services. Eripek (Ed.), Special Education (17-22). Eskisehir: Anadolu University Publication, Issue:1018.

Koçyiğit S, Kayılı G, Yıldırım Doğru SS, Çiftçi, S. (2010). Kaynaştırma eğitimi dersinin okul öncesi öğretmeni adaylarının kaynaştırmaya ilişkin görüşlerine etkisinin incelenmesi. Mehmet Akif Ersoy Üniversitesi Eğitim Fakültesi Dergisi, 20(10), 48-65.

Konar N, YildiranI (2012). physical education and sports teaching for the diasabled: requirements and a programme model, Selcuk University Physical Education and Sport Science Journal , 14 (2): 208-216

Mackey M (2014).Inclusive education in the usa: secondary school teachers' approaches for the inclusion, International Journal of Instruction July 2014, Vol.7, No.2 
Aydın, M., İra, N., Meriç Bingül, B., \& Bulgan, C.. (2016). Physical education and sports students' attitudes towards inclusive education (The sample of Kocaeli University). Journal of Human Sciences, 13(2), 2839-2846. doi:10.14687/ihs.v13i2.3667

Morley, D.,Bailey, R., Tan, J.,Cooke, B (2005) Inclusive physical education: teachers' views of including pupils with special educational needs and/or disabilities in physical education, European Physical Education Review, 11: 84

Orel A, Zerey Z \&Töret, G. (2004). Sınıf öğretmeni adaylanının kaynaştırmaya yönelik

tutumlarının incelenmesi. Ankara Üniversitesi Eğitim Bilimleri Fakültesi Ö̌rel Eğitim Dergisi, 5 (1), 23-33.

Ozdemir H, Ahmetoglu E (2012). Examining the views of pre-school teachers about the inclusion with respect to their ages and experience, Journal of Educational and Instructional Studies in the World February, volume: 2 Issue: 1 article: 11

OzerDS(2001)."Physical Education and Sports for the Disabled", Ankara: Nobel Publications Distributions

Ozturk H, Ballioglu G, Sen G (2014), Examining the attitudes s of pre-service teachers toward the inclusion in special education, MuglaEducational Faculty Journal / Volume 1. Number 1

Sart H, Ala H, Yazlik O, Kantas-Yilmaz, F (2004).Where is turkey in inclusive education? suggestions to the instructor $13^{\text {th }}$ international congress of educational sciences 6-9 July, 2004, Inonu University Education Faculty, Malatya

Secer H, Celikoz N, Sari H, Cetin S, Buyuktaskapu S (2010). The attitudes of teachers employed at pre-school educational institutions towards inclusive education (Konya Province), Selcuk University Abmet Kelesoglu Educational Faculty Journal Issue: 29, Page: 393-406,

Sezer F (2012): Preventive guidance work for developing favourable attitudes towards people with disabilities; an experimental application.Journal of New World Sciences Academy Volume: 7, Number: 1, Article Number: 1C0471

Sonuc A (2012). The effect of sport on the anger level of the mentally disabled. Karamanoğlu Mehmetbey University Social Sciences Institute, Thesis of Master's Degree

Türkoğlu, Y. K. (2007). İlköğretim okulu öğretmenleri ile gerçekleştirilen bilgilendirme çalışmalarının öncesi ve sonrasında öğretmenlerin kaynaştırmaya ilişkin görüşlerinin incelenmesi. yayınlanmamış Yüksek Lisans Tezi. Anadolu Üniversitesi, Eğitim Bilimleri Enstitüsü, Eskişehir.

Vural, (2010), The Evaluation of the application of inclusion at elementary schools, trministry of education, Directorate of Educational Research and Development, http://www.meb.gov.tr/earged/earged/ilk kaynas eg_uyg_deg.pdf, (Access Date: 26.08.2015) 